\title{
Beyond (anti)utilitarianism: khat and alternatives to growth in northern Madagascar
}

\author{
Lisa L. Gezon ${ }^{1}$ \\ University of West Georgia, USA
}

\begin{abstract}
:
Madagascar has one of the lowest GDPs in the world. Colonization brought the country into the global economy, but left it at its margins - vulnerable to the hardships of structural adjustment and limitations of state infrastructure. This analysis reveals economic decision-making that defies the utilitarian logic of homo economicus and inspires creative thinking about alternatives to growth as a dominant paradigm. In northern Madagascar, the economy of the stimulant khat is part of one socionatural world characterized by low levels of production and consumption. Madagascar provides a case study for suggesting that "making a living" invokes an intricate web of material desires, cultural meaning, and social connections that do not necessarily revolve around a capitalist growth motive. This article proposes that a path to sustainability is not only in changing social imaginaries but also in valorizing and leveraging cognitive orientations and practices that exist but that may fall below the radar of traditional economic analysis.
\end{abstract}

Keywords: Madagascar, khat, utilitarian, degrowth, economy, urban

\section{Résumé:}

Le Madagascar a un des PIB les plus bas au monde. La colonisation a ouvert le pays à l'économie mondiale, mais l'a laissé dans les marges-vulnérable aux difficultés d'ajustement structurel et aux limites des infrastructures de l'état. Cette analyse montre les prises de décisions économiques qui défient la logique utilitariste de l'homo economicus, et elles inspirent une pensée créative qui conçoit des alternatives de croissance comme paradigme prédominant. Dans le nord du Madagascar, l'économie du stimulant khat fait partie d'un des mondes socio-naturels caractérisé par de bas niveaux de production et consommation. Madagascar fournit une étude de cas qui le fait de "gagner sa vie » qui invoque un réseau de désirs matériels, de signification culturelle, ainsi que d'appartenance sociale qui ne gravitent point autour d'une motivation de croissance capitaliste. Cet article propose que le chemin vers la durabilité ne réside pas seulement dans le changement des imaginaires sociaux, mais dans la valorisation et l'appropriation d'orientations cognitives et de pratiques qui existent mais qui ne sont pas détectées dans les analyses économiques traditionnelles.

Mots clés: Madagascar, khat, utilitarisme, décroissance, économie, urbain

\section{Resumen}

Madagascar tiene uno de los PIB más bajos del mundo. La colonización connectó el país con la economía global, pero lo dejó a sus márgenes, vulnerable a las dificultades del ajuste estructural y las limitaciones de la infraestructura estatal. Este análisis revela un caso en que la toma de decisiones económicas desafía la lógica utilitaria del homo economicus y así inspira el pensamiento creativo sobre alternativas al crecimiento como paradigma dominante. En el norte de Madagascar, la economía del khat, un estimulante, es parte de un mundo socio-natural caracterizado por bajos niveles de producción y consumo. Este caso de estudio en Madagascar sugiere que, en algunos contextos, la idea de "hacerse la vida" invoca una intrincada red de

\footnotetext{
${ }^{1}$ Dr. Lisa L. Gezon, Professor of Anthropology, University of West Georgia, Carrollton, GA, USA. Email: lgezon "at" westga.edu. I wish to thank Susan Paulson and Karen Foster for their helpful comments, as well as each of the authors in this Special Section for their stimulating ideas. Any shortcomings remain the responsibility of the author. Thanks also to Casey Walsh for important editorial feedback. Finally, I would like to acknowledge the help and inspiration of so many colleagues, friends, and contacts in Madagascar, including Ghislain Gaspard, Jacqueline Benivo, Louis-Philippe d'Arvissenet, and Alex Totomarivariou. This is the ninth article in Lisa L. Gezon and Susan Paulson (eds.) 2017. "Degrowth, culture and power", Special Section of the Journal of Political Ecology, 24: 425-666.
} 
deseos materiales, significados culturales y conexiones sociales que no giran, necesariamente, alrededor de un motivo de crecimiento capitalista. Este artículo propone que uno de los caminos a la sostenibilidad no es sólo inventar nuevos imaginarios sociales sino también valorar y aprovechar las orientaciones y prácticas cognitivas que existen pero que pueden pasar desapercibidas en los análisis económicos tradicionales.

Palabras clave: Madagascar, khat, utilitario, decrecimiento, urbano

\section{Introduction}

While doing research in Madagascar in the summer of 2015, I visited an urban Malagasy healer and spirit medium who treated people for a wide range of problems, including physical ailments, troubled relationships, and problems meeting their material needs. He told me that his trade will always remain relevant, that people will always need spirit mediums who channel advice from ancestors. He explained that this is because people will always experience some kind of brokenness in their lives. While this may be generally true of the human condition, I saw a relationship between urban healer and client that is situated within a particular historical, cultural, and economic context of survival. Making a living exists within a complex web of desires, relationships, and practices - this particular web seems to defy the utilitarian logic of homo economicus and inspire creative thinking about alternatives to growth as a dominant paradigm.

This analysis reveals an economy that has a relatively low energetic flow-through. It is an economy not of 'degrowth,' as in downsizing, but rather one that has been described by a long-time resident in Madagascar as an economy of 'no-growth,' or an economy of survival (une économie de survie) in the wake of colonization that left it at the margins of the global economy, with one of the lowest GDPs in the world, vulnerable to postcolonial hardships including structural adjustment and limitations of state infrastructure. Unlike many analyses of degrowth movements occurring in the global North, this analysis is not about voluntary simplicity as a way to reduce ecological footprints, nor is it a tale of a grassroots movement proactively searching alternatives to capitalism, such as Buen Vivir (Gudynas 2015). It is about the ways many people in northern Madagascar have co-created living conditions where their lack of power limits their access to material resources.

I have argued elsewhere (Gezon 2016) that the khat economy could be seen as a public secret. It is an economy that can be interpreted as alternative to the global capitalist economy because its aims are more oriented toward continuity and subsistence than toward expansion and capital accumulation. This article takes that argument further by reflecting on the question of how to meet basic human needs and desires while avoiding a paradigm of perpetual growth. This analysis draws on political ecology as a lens for analyzing how people respond to challenging economic conditions. In dialogue with degrowth literature, I argue that recognizing and valorizing these local responses to material imbalances will be useful in addressing poverty reduction in a sustainable way. I argue further that a path to sustainability is therefore not only in changing social imaginaries but also in valorizing and leveraging ones that exist, but that may fall below the radar of traditional economic analysis and the cultural and political ideology in which it is embedded-or even be condemned by neoclassical economists as lazy and unproductive. Understanding how people actually construct and fulfill desires at the local level critically challenges a narrow neoclassical economic vision of individualistic, utilitarian actors and challenges the common assumption that capitalism is natural and the point of departure from which all analyses begin.

The case of Madagascar does not reveal a neat tale of either participation in or defiance of global capitalism. Local people engage in capitalist-oriented consumption, for example, even if they do not aim to accumulate profit for the purpose of reinvesting in the means of production or in the financial system. The global capitalist economy has produced consumer items and provoked associations of these items with prestige and/or convenience in many locales and among a wide cross-section of social classes around the world-such things as vehicles, entertainment technology, clothing, food, homes and appliances, etc. Many clients of the traditional healer introduced above desired those items. He himself proudly displayed a large, expensive stereo system, and blasted popular music from his television through speakers that filled the tiny urban courtyard he shared with about ten other one-room dwellings, whose residents shared a water spigot and sanitary facilities. 
In addition to cash, the clients often had to provide gifts for the ancestor spirits that indexed something about that spirit's identity and personal tastes: cigarettes, local rum, and beer were common. The items would often be consumed during the session. These exchanges reveal interwoven cultural frameworks of ethnic identity, religion and cosmology (Sharp 1996), contexts of mental and physical healing, the experience of pleasure in certain forms of shared consumption, and the value of social connections through the gifting practice. Making a living blurs distinctions between cultural, social, and material pursuits.

Few people in a place like Antsiranana, Madagascar, can afford consumer goods like the healer's stereo and television, but many would say they want them, and many of those people would be on the lookout for opportunities to obtain them, either through purchase, barter, or gift. Yet in Antsiranana, as in many parts of the global South, there are few formal sector opportunities available for obtaining cash needed to buy any of those goods or even basic food, health, and education needs. To fill this void, semi-autonomous economies have thrived on the outside edges of what economists call the formal economic sector-the formally documented activities that contribute to the calculation of Gross National Product. In northern Madagascar, the growing, buying, and selling of the drug crop khat occupies this space and provides many with a source of income.

The Malagasy khat economy is significant to this analysis for two reasons. First, growing and selling khat provides options for many people in this region to obtain currency for purchasing things-even in the absence of formal employment. Second, khat exists within a total social context where it provides more than just cash. The growing, distributing, and consumption of it is also part of a lifestyle. And, significant to this analysis, as a consumed item, khat affords relatively easy access to pleasures, social relations, and fulfillment of desires that do not require accumulation of material goods. Khat is part of a cultural and economic framework where people buy and sell, give and receive, motivated by factors that intertwine pragmatic economic self-interest to an embracing of style, identity, and social connections.

In the analysis to follow, I will provide a background on khat in northern Madagascar, followed by a more in-depth look into how khat fits into local livelihood strategies. A critique of a 'utilitarian' model for understanding economic behavior will follow. I will then propose a political ecology approach to degrowth with objectives both of understanding how people adjust to threats from uneven resource distribution and of seeking alternatives to economic growth as a model for the pursuit of quality of life. This analysis is based on ethnographic research in northern Madagascar that I have carried on intermittently since the early 1990s. My research on khat in particular took place in the region of Diego Suarez for six months in 2004, with follow-up one-month visits in 2005, 2007, 2010, and 2015, where I used multiple methods for understanding the khat commodity chain, including surveys, interviews, general observation, mapping and satellite image analysis, and food diaries (Gezon 2010a). My aim was to elaborate the commodity chain of khat, showing the ways in which this locally-marketed drug crop provides a living for many farmers and traders and increases the local flow of currency (Gezon 2010b, 2012).

\section{Khat in its commodity chain}

Most scholars accept that khat was being used recreationally in Yemen and Ethiopia by the 12th century and became widespread by the 14th century. In the contemporary era, khat is mainly consumed in Yemen, east Africa, including Ethiopia, Kenya, Djibouti, and Somalia; and in places with significant Somali immigrant populations (Anderson and Carrier 2011; Carrier and Gezon 2009). Ethiopia and Kenya are the two main producers in east Africa, and they are the main suppliers of khat to the world. Chewing khat has been an important social and political ritual in Yemen and Ethiopia for hundreds of years and is also deeply rooted in Meru cultural practices in Kenya (Carrier and Gezon 2009).

In Madagascar today, the main centers of khat production are two large villages to the north and northwest of the Amber Mountain National Park, about 30 miles south of the regional capital, Antsiranana, or Diego Suarez. Khat is mainly cultivated by smallholders who farm less than 2 hectares. Because of this, many farmers have the opportunity to earn from khat production. Khat first arrived during the French colonial era, when Yemeni dock workers brought it with them (Weir 1985: 19). The first to grow it commercially, according to interviews, were the Creoles-white farmers of French descent who came over 
from Ile de la Reunion around the turn of the century-who had concessions on the fertile foothills of the volcanic Amber Mountain.

The pulse of street economy of the northern city of Diego Suarez is fueled by the khat trade. Some sellers have family ties to the growers of khat, but most have gotten into it through various connections, either in the city or in the rural areas where it is grown. There is much fluidity of movement between the city and the khat rural production areas, and it is not unusual for a vendor living in the city to travel to a village each day to buy khat wholesale.

Until the early 1990s, khat was mainly consumed by those who identified as Yemeni descended (locally referred to, and self-identified, as arabou). In the past 20 or so years, khat-chewing has gained significant popularity among the broader Malagasy population-particularly among those identifying as coastal peoples. Many concur that the taxi drivers were among the first to chew it in order to keep themselves awake while they worked at night. Khat chewing gradually caught on. Men are the most visible chewers and more men chew than women, but there is little stigma attached to women who do chew khat. Those who now chew regularly include workers with stable incomes and youth without fixed or formal sector incomes. Whatever their social standing, all chewers reported finding it an enjoyable way to pass time with friends or by themselves. Khat chewers say that it opens up thoughtful conversations on politics and current events and also allows them to think about how to improve their individual lives and to alleviate their worries (mañadoso asa loha) (Gezon 2013, see also Mains 2010).

In different contexts of consumption around the world, khat has become increasingly popular among new communities of use-particularly among women and youth - in rural areas as well as urban centers. Wherever khat is chewed, it forms an important part of identity and social interaction (Carrier 2005; Mains 2010). In Diego, it has cross-cut ethnicity and even social class in forging new associations between people in this urban setting (Pierre Mbima, pers. comm.). Chewing khat is also central to the identity of many young men in Diego Suarez, some of whom self-identify as koroko. This is a subcultural network of young men who speak a slang by that same name and share a distinct identity as hip and attuned to a global youth culture of hip hop music and fashion (Mbima 2006). Although these minimally employed young men in general eschew career aspirations and the need to work for money, most do part-time informal sector or seasonal work, including khat-selling. Many women involved in transactional sex labor also use khat to stay awake and for comradery (Betina Torbjornsen pers. comm.).

\section{Living with no-growth in urban Madagascar}

The challenge for people in urban northern Madagascar is to make a living where it is impossible to compete successfully in the global capitalist economy. They have had to adjust to a changing political and economic landscape where destitution has been a palpable adversary. I am use the language of adaptation to illustrate this process. According to the American Anthropological Association's Global Climate Change Task Force report, "[a]daptation generally refers to changes in beliefs or behaviors in response to altered circumstances to improve living conditions, including a culturally meaningful life" (Fiske et al. 2014: 42). In this sense, adaptation refers to the ways people actively co-create their worlds. Although the term comes from an ecological paradigm, it does not need to be limited to the description of unproblematic natural laws. Rather, it can be used to describe cultural, political, and economic negotiations of power and access to unevenly distributed material resources. Scholars have drawn on political ecology in tracing adaptations at the urban level, considering such issues as access to land and fair housing (Rademacher 2009), making a living from urban waste and raising hogs (Moates 2004), and the rural-urban linkages that facilitate urban survival (Lesetedi 2003).

Political ecology considers the ways in which human decision-making shapes the distribution and use of biophysical resources, focusing particularly on the role of power and the effects of extra-local processes. A political ecology approach is useful for understanding how people make a living in contemporary urban Madagascar. Life in the quartiers populaires (poor, working class neighborhoods) of urban Diego Suarez, Madagascar bears marks of culturally specific interactions with historical political and economic circumstances. Madagascar was under French rule from 1896-1960, followed by President Tsiranana from 1960-1972, who worked closely with the French and perpetuated many colonial-era relationships. A socialist 
revolution in 1972 overthrew Tsiranana and brought Didier Ratsiraka to power in 1975. After a period of heavy borrowing from the World Bank and failed investment initiatives in the late 1970s, Madagascar's debt burden quadrupled, leaving it no option but to undergo structural adjustment. It accepted aid from the International Monetary Fund (IMF) beginning in 1980 (Gezon 2006). With Madagascar paying 85\% of its export earnings to service their debt by the late 1980s, the country had little left for maintaining and developing basic infrastructure of roads, education, and healthcare (Gezon 2006). Since then, political instability and inability to compete on a global level has kept Madagascar poor according to mainstream economic measures. Its GDP per capita is $217^{\text {th }}$ out of 230 nations (https://www.cia.gov/library/publications/the-world-factbook/rankorder/2004rank.html\#ma).

Khat is also a major means of subsistence for northern Madagascar. Khat, which has been described as the "green gold" of the north, circulates almost entirely outside of the purview of government record keeping and tax collecting. It is grown for consumption mostly within the local province of Antsiranana, with some going by plane to other regions of the country. People do not sell khat in large quantities internationally, even illegally. As in other countries where it is grown, khat receives little to no attention from agricultural extension agents either at the national or international donor level. In the mid- to late-2000s, there was a rumor that the then-president of Madagascar Marc Ravaolmanana (President from 2002-2009) denounced khat consumption as bad for economic development. In 2008, a rumor spread that the government was considering making khat illegal, and I was told that it nearly incited a riot.

Khat is part of a larger framework of making a living in northern Madagascar, which includes remittances and both formal and informal sector employment locally. Gerard's story is common. He is in his early 20s and eats with his grandmother, who has raised him much of his life. He sleeps in a nearby rented room along with his girlfriend and their infant son. His grandmother rents a room in an urban courtyard, where there is a narrow alley between the one-room dwellings and where the residents share sanitary facilities and a water spigot. I got to know him because his grandmother is my classificatory older sister, traced through rural connections to the fertile rice-growing region where I did my first fieldwork in the early 1990s (Gezon 2006). I have known him, in fact, since he was a young boy. My older sister had originally moved from a farming village to the city in the 1960s after a divorce in order to make a living entertaining foreign men and doing domestic labor.

I visited her in the summer of 2015 with the intention of learning about the micro-economics of adapatation in one of the poorest sections of the city, where formal employment was rare. After spending several days with her, I began to understand some of the intricacies of making a living. She told me that only one of her progeny had a formal sector job (as a chauffeur) and that she lived primarily on money sent to her from a relative living in France_-common for many people in Diego Suarez.

Gerard's activities become clearer when I started asking him about chewing khat. Yes, he chews it when he hangs around the garage where he goes daily, and where he works part-time when there is work. Sometimes he buys khat and sometimes his boss (patron) buys it for him. Gerard's boss incorporates him into his life to some extent by inviting Gerard to take short trips with him. The boss also sells Gerard some of his cast-off goods cheaply. One day I arrived at the home of Gerard and my sister and saw a large set of speakers and heard them filling the small courtyard with music. My sister told me that Gerard had gotten them from his boss and that they were going to pay them off little by little with her remittance.

This relationship of dependence on his boss-for work, leisure through khat chewing and sociable conviviality at the garage, for excursions, and for access to credit for luxury goods - is reminiscent of James Ferguson's discussion of the importance of "relations of social dependence as the very foundation of polities and persons alike" (2013: 223). He writes that perhaps: "South African capitalism and 'modernization' did not do away with personalistic and dependent relations between employer and employee" (p.228). Ferguson argues that what is misleadingly referred to as the informal economy is saturated with life-giving social interdependencies. The economy is not "informal" since it functions via highly organized, ritualized, and meaning-imbued relationships and practices. This echoes the observations of Andrew Walsh (2003, 2012), who has studied economics and social exchange in a mining frontier town south of Diego Suarez, Madagascar. 
Khat, like any commodity, cannot be abstracted from its part in pleasure, identity-formation, and social bonding. It is common mid-afternoon in Diego, after the mid-day arrival of khat from the countryside, to see groups of young men chewing khat on the side of the streets, often playing cards. Gerard, his fellow part-time laborers, and their boss often chew khat together in the afternoons. Embedded within this lies an array of social exchanges that are meaningful and satisfying. Each realizes pragmatic gains: Gerard gains access to an informal line of credit through his boss and access to cash in exchange for occasional work. His boss gets access to labor in exchange for pay on occasional basis, which allows him to maximize his business without paying a fulltime salary. Yet each participates in this for more than utilitarian reasons: the cash that Gerard does earn allows him to exercise his own subcultural distinction through the purchase of clothing fit for a well-dressed, hip urban youth. For Gerard, his fellow part-time laborers, and their boss, this arrangement provided social interconnectedness, conviviality, and meaningful identities.

In addition to his relationship with his boss, Gerard also engaged in mutual dependencies with social equals. When he was not at work, he and his girlfriend spent some of their afternoons hanging around the courtyard interacting in meaningful and convivial ways: one day Gerard was trimming someone's eyebrows, and another day his girlfriend was doing someone's hair in the alleyway. The interdependencies cross-cut social and economic aspects of life and are critical to holistic survival and well-being.

The flexible nature of this kind of work, common among young khat chewers in Diego, enables these laborers to keep some autonomy over their own schedules and to work when it fits in with other demands. The Malagasy linguist Pierre Mbima (pers. comm.) explained this cultural orientation towards labor. He said that the koroko-identified youth pride themselves in working as little as possible. They resist formal sector employment and seek out seasonal employment or odd jobs when they do need cash. He said that in resisting the stigma of poverty, many young men have come to embrace the practice of chewing khat as a symbol of a different kind of ease: chewing khat symbolizes that one does not need to work to be fulfilled. Although many do work, many seek to work on their own terms and seek a personal aesthetic that shows that.

This stance toward labor creates the impression of laziness in the eyes of people oriented toward global capitalist development. Many educated professionals in the city of Diego, including politicians, government bureaucrats, legal professionals, and religious leaders, expressed concern that khat consumption stands in the way of development. Surveys we conducted in the Diego in 2010, however, revealed that few khat chewers or common citizens agree with the assertion that khat makes people lazy. They know that the khat chewing that people see on the streets does not represent a complete story: they know that khat is a stimulant that many people-including many of those who chew on the streets-chew it in order to work harder, albeit often in the so-called informal sector. Khat's drug effects are complex and culturally mediated. They often include periods both of energized euphoria and introspection (Gezon 2013), and so it is difficult to make simple generalizations about its effects.

In addition to being an economy oriented toward meeting local needs, the cultural economy of khat embraces its own set of goals, motivations, and rewards-ones that do not always line up with the Weberian work ethic that is an important contributor to growth-oriented capitalism. People familiar with the construction industry in Diego Suarez commonly comment on how hard it is to get local Malagasy people to work on major public works projects, such as road or building construction. I heard more than once that companies had tried to hire locals but that eventually they had to send for people from the central part of the country who were willing to work under their terms of contract. When I asked local people about this, they told me that the rate of pay was so low that it barely covered their expenses, and they did not like the inflexible hours and requirements to be there every day. They also have other ways of earning money, many of which are entrepreneurial (such as buying and selling khat). They also embrace ways of being that seem inconsistent with orientation toward profit, but which embrace other survival and life satisfaction-oriented values, such as mutual interdependence and leisure.

Being accused of being lazy is not unique to northern Madagascar. Chewers of khat have generally been accused of being lazy, be it in Ethiopia, Kenya (Carrier 2008), or elsewhere. Colonial subjects and the underclass are commonly described as lazy. The 'crime' and supposed moral corruption of laziness has commonly been issued at people who are not in a structural position to benefit from capitalism but who are taken, ironically, as being the cause of their own economically marginal status (see also Harris 2005). Syed 
Hussein Alatas, who sought to uncover the myth of the 'lazy native' in southeast Asia, noted that "[a]ny type of labour which did not conform to [the capitalist conception of labor] was rejected as deviation," (Alatas 1977: 70) and "[t]he accusation of indolence was merely a veiled resentment against Malay unwillingness to become a tool for enriching colonial planters" (p. 80-81). A similar explanation could be applied to urban Madagascar. Despite their lack of financial power, marginalized people around the world negotiate the conditions of their lives in significant ways.

\section{Beyond (anti)utilitarianism}

The discourse of laziness is part of a discussion of motivation, desire, and ultimate ends met through means that may be incomprehensible within a narrow neoclassical economic analysis. As a player on the margins of the global economy, people like Gerard, his boss, his kin, and his neighbors participate in an economy that meets multiple needs, including conviviality (Romano 2015), social connection, and identity, as they are meeting basic material needs. Not only does this economic orientation defy a simple dichotomy between utilitarian and anti-utilitarian (which is a critique relevant to all economic systems), but it also points to a system where orientation toward economic growth is not dominant (see also Wolf 1966). Deconstructing abstract neoclassical economic analyses of capitalism paves the way for bringing existing complexities into focus as well as imagining alternatives.

One criticism of capitalism, defined as an orientation toward economic growth for profit, challenges the ecological sustainability of its mandate for growth (O'Connor 1988; Latouche 2009). A critique that is more central to this analysis contests the hegemony of neoclassical economic thought as a way of describing how humans make a living. Economics, as an academic discipline, co-evolved with the Industrial Revolution and the Protestant work ethic, which introduced not only new economic forms of production and exchange, but also new forms of subjectivity. As a cognitive framework, Polanyi (1968 [1944]) explains that neoclassical economics has co-created, explained, and maintained capitalistic conditions. It focused on the distribution of goods and services through supply and demand and on individuated actors who were fully accountable for their productivity. He explained that the principle of the contract separated people from kin, neighbors, professional colleagues, and fellow religious adherents, since "they claimed the allegiance of the individual and thus restrained his freedom" (1968 [1944]: 163). Polanyi notes that this was devastating for colonized regions as well as for Europe, since people were forced to sell their labor and destroy traditional institutions that had protected them from destitution.

A ground-level and cross-cultural analysis of making a living also challenges the abstract capitalist model of human behavior, where homo economicus, by virtue of basic human nature, knows what it wants and seeks to get as much as possible for as little effort as possible through profit gained from barter and exchange (Graeber 2001: 6). Economic anthropologists such as Polanyi argue that the notion of a selfinterested 'rational actor' is an idealized model and not derived from on-the-ground observations (1977). His substantivist approach, which insists that the exchange of goods and services can only be understood in social and cultural context, contrasts with a formalist approach that focuses on calculated self-interest in the face of scarce resources. He challenges the market principle as the natural organizing factor in making a living, pointing out the recent and artificial nature of a supra-local market system (Polanyi 1968 [1944]). A crosscultural comparative approach has provided anthropologists with the tools to challenge the universality of the capitalist market principle based on ethnographic examples, such as the Melanesian kula ring and the potlatch of the Pacific Northwest (Sahlins 1972). Marshall Sahlins concludes Stone age economics with the reflection that he has presented the reverse of economic orthodoxy through his "discourse on economics in which 'economizing' appears mainly as an exogenous factor!" He continues to muse that "it may be worthwhile to see how far this heresy will get us" (Sahlins 1972: 230).

Sahlins went on to remark that conceiving of things only in terms of exchange-value "ignores the cultural code of concrete properties governing 'utility' and so remains unable to account for what is in fact produced" (1976: 166). He points out that the principle of unlimited wants and scarce means cannot be generalized across subsistence strategies, and that in non-capitalist economic relations, transactions are intricately tied in with social and moral interests (Sahlins 1972). Together, Polanyi and Sahlins demonstrate that the capitalist market principle, with its rational actors motivated by self-interested profit, is neither 
universal nor as simple as it appears even within capitalistic market economies: what is rational is always shaped within cultural contexts. As such, assuming a universal dichotomy between utilitarian actions (selfinterested market-oriented, based on material gain) and anti-utilitarian actions (oriented toward pleasure, social connection, and identity) is an ideological construction.

These critiques resonate with scholars writing about degrowth, who challenge the principle of growth as the basis for a global economy (D'Alisa et al. 2015; Latouche 2009). Paulson (2015: 46), for example, argued for "more sophisticated understandings of consumption that do not separate putative 'physical necessities' from 'cultural choices'." Others argue that while people often conceive of the growth-oriented market as inevitable and 'natural,' it is in fact a dogma akin to religion (Cattaneo 2012). Degrowth is at once a social movement and a heterogeneous academic discussion that challenges the global capitalist ethic of growth in the production of goods and services, calling for ecological and social sustainability. Considering social sustainability, two major axes stand out: first is an existential question about fulfillment, and the second considers social disparities in access to resources. Along the first axis, degrowth scholars problematize motivation and fulfillment, proposing that social desirables and material needs are inherently linked and that they lie both within and outside of the market sphere. Consumption is a cultural and a social process that serves as a means for navigating social relationships and concretizing cultural constructions (Appadurai 1998; Douglas and Isherwood 1979). Indeed, consumption choices index such characteristics as social class, cultural alignments, and moral character. Degrowth scholars point out that often ignored needs include "equity,...free time, sense of community, participatory democracy, ... life expectancy and subjective well-being" (Kallis et al. 2012: 175). In addition, they also show that there is no necessary connection between resource accumulation and happiness (Schor 2010; Sekulova 2015).

Recognizing the cultural and historical nature of neoclassical economic constructions is liberating, and degrowth scholars use it as a point of departure in their call for to unshackle our thinking about making a living and to find creative replacements for practices and policies based in capitalist relations. The economy in northern Madagascar - one that includes both 'formal sector' and 'informal sector' exchanges of goods and services - illustrates the ways that desires play themselves out beyond the oppositions of 'utilitarian' versus 'anti-utilitarian' behaviors and ideologies. Gerard, for example, illustrates this complexity of needs, desires, and connections. He, and many like him, seek food and shelter, but not in just any form. Camaraderie, flexibility in scheduling, and clothing and the social recognition that comes with it are particularly important. His grandmother, on the other hand, cares less for clothing and more about keeping the rent and utilities paid and having high quality, nutritious food available. She also cares about the emotional and social connections she has with various extended family members - some of whom she helps and others of whom she relies upon financially. They pursue these goals through a combination of self-interested market transactions, social connectedness, and cultural presentations of self and identity. They all care deeply about the quality of relationships they have with others, out of an emotional sense of human connection and in recognition that survival is not possible without them. Similarly, in writing about rural Canada, Karen Foster (2017) critically examines the work ethic and disentangles it from a productivist orientation. These stories can inspire our thinking about aspirational as well as existing degrowth-oriented alternatives to the hegemonic global capitalist economy. ${ }^{2}$ As Paulson (2017: 426) points out, "ideals of degrowth call us to shift value and desire away from productivist achievements and consumption-based identities toward visions of good life variously characterized by health, harmony, pleasure, and vitality among humans and ecosystems."

\section{Political ecology and degrowth}

Overconsumption and uneven global resource distribution threaten social and ecological sustainability (Kallis et al. 2012). Social inequality has been rapidly expanding in recent decades both between the global North and South and at the national level within most countries (Gilmore 2013). As a perspective that focuses holistically on power dynamics involved in local and global processes of resource access, political

\footnotetext{
${ }^{2}$ See Escobar (2008), Gibson-Graham (1996, 2014), and Narotzky and Besnier (2014) for a discussion of alternative economies.
} 
ecology works well with degrowth thinking about the interlinked goals of how to increase global equity and reduce ecological degradation (Paulson 2015).

In response to current social and ecological challenges, many degrowth thinkers have called for reducing consumption and the overall scale of the economy (Cattaneo 2012; Latouche 2009). Much of the call for this downsizing is aimed at the global North in general and at elites globally because of the large amount of resources they control and consume. Considering what degrowth means in the context of the global South and for economically disenfranchised people is a different, though related, challenge. In this issue, Paulson (2017) argues that reducing global inequities calls for growth where it contributes to increases in healthcare, education, and other welfare. Latouche (2004) argued that the South would be best off if it disentangled from the North's economy, but that this could only occur of the global North's economy simultaneously contracts. He noted that this involves reviving cultural histories of "anti-economistic values" and further pointed out that "fresh and original alternatives springing up point the way towards a successful post-development society." Kallis et al. (2015: 5) similarly argued for the need to "liberate conceptual space for countries there [in the global South] to find their own trajectories to what they define as the good life," emphasis in original).

John Bellamy Foster (2011), however, argued that the South needs more than a conceptual shift. It also requires structural and practical initiatives aimed at "overcoming imperial linkages, transforming the existing mode of production, and creating sustainable-egalitarian productive possibilities." He makes a case for sustainable development aimed not at growth but at meeting needs for water, food, and healthcare. Arturo Escobar (2015) combines these positions, arguing for both practical action and creative cognitive frameworks. He remarked that the North should avoid the argument that "while the North needs to degrow, the South needs [growth-oriented] 'development"' (Escobar 2015: 456). The South must avoid looking to growth as the unavoidable source of improvements, since capitalist growth tends to exacerbate social inequality.

In considering the connections between postdevelopment and degrowth scholarship, Escobar points out the value of critiquing modernity through the historical lens of colonialism (2015). He looks to the postcolonial and decolonial theories of such writers as Vandana Shiva and Ashis Nandy. They critique the goals of development as promoted by the Bretton Woods institutions and seek holistic development and quality of life instead of looking to a rise in GDP or even a lowering of poverty statistics as measures of wellbeing. Nandy, for example, argued for disentangling poverty from destitution, taking issue with a system that marks "all low-consuming, environment-friendly lifestyles as poor and, thus, degrading and unfit for survival in the contemporary world" (2002: 115). He argued for the kind of 'poverty' that embraces dignity, social interdependency, and environmental sustainability.

Instead of issuing proscriptive ideals, Brian Gilmore poses the question about what people want on the ground. He notes, in particular, the potential reluctance of the economically disenfranchised in the global North (African Americans in the U.S. in particular) and in the global South to embrace degrowth, and relates this to their long history of racial inequality and imperialism. He writes that "nations in the developing world likely aspire to some aspects of the West in order to improve the lives of citizens in their countries. Black Americans, in particular...might be found to be quite reluctant in rejecting the benefits of Western life" (Gilmore 2013: 1287). Many desire not only basic necessities but also luxury goods and technology in order to participate in global communication networks. Being aware of the complexities of aspiration underscores the need for interventions that encourage people to choose sustainable and fulfilling means to desired ends.

The face of consumption and values that accompany it will differ in time, space, and social group, but everywhere, we can expect to see desire for basic material needs combine with desire for prestige, identity, and connection. Ethnographers are trained to seek to understand the emic perspective- that of the people being studied-and let it inform our analyses. Gibson-Graham (2014) advocates 'weak theory' that resists blanket abstractions, but rather seeks patterns and values the context and diversity provided by case studies. Taking this approach helps avoid pitfalls of dualistic thinking. This Madagascar case suggests that one cannot easily juxtapose 'Western' versus "distinct indigenous cultural identities" (Latouche 2004) and local economic alternatives, since they are intricately intermeshed and complicated to tease out. The healer's (see beginning of the article) loud sound system, for example, features a product of the global capitalist economy 
(the sound system), acquired as private property as a result of accumulated profit from treating clients. Yet it was a symbolic marker of identity shaped and made meaningful within a local set of values: being set up in the middle of a shared courtyard, he shared his bounty with others. At the same time, he turned his profit into prestige as the provider of this luxury.

Similar to the analysis of private versus collectively-managed property by DeVore (2017), classic dualities become blurry when observed on the ground. Monetary exchange based on utilitarian self-interest combines with urban community and kin commitments, locally meaningful forms of identity and sharing, and, in the case of the healer, the kind of care and nurturing associated with successful healing. Local interpretations of modernity include and embrace capitalist-oriented consumption, even if they do not aim to accumulate profit for the purpose of reinvesting in the means of production or in the financial system. This analysis also echoes Demmer and Hummel's (2016) caution about romanticizing non-capitalist livelihood strategies as being free from any form of egoistic interest. Being aware of these intricacies strengthens degrowth as a movement, since it makes it better prepared to develop viable alternatives based on lived experiences. Degrowth and political ecology are similar in their examination of social inequalities and environmental degradation. As an analytical approach, political ecology contributes to degrowth through grounded inquiry into the ways people adapt to challenges, both in the global South and North, and in using those insights to work toward effective change.

\section{Concluding thoughts}

A political ecology approach echoes degrowth scholars and activists by underscoring the value not only of critiquing capitalism but of exploring, presenting and encouraging alternative ways of being (see also Burke and Shear 2014). Through the lens of degrowth transitional discourses, the example of Madagascar provides a case study of a non-capitalist alternative that defies an easy dichotomy between utilitarian and anti-utilitarian motivations. The case of Gerard illustrates the multifaceted ways that people adapt to the threat of destitution on the edges of the global capitalist economy. Understanding khat as operating outside of the workings of the formal economy and the logic of accumulation is valuable not only because it exonerates the supposedly lazy 'natives' from the 'crime' of irrationality: it also points in a direction that some argue could save our planet because of its orientation toward holistic wellbeing and localized, subsistence-oriented resource use. Blaikie and Brookfield (1987) made what at the time seemed a bold statement, in arguing that soil degradation is not a technical but a social problem. That observation is still important for degrowth thinking today: technological solutions will not solve environmental crises since the crises are first and foremost social problems rooted in unequal control over and access to resources.

The recognition of the multiple facets of making a living is important for both prescriptive and descriptive reasons. Descriptively, it provides a lens for describing behaviors and motivations that appear to lie outside of the rational actor framework, particularly voluntary simplicity and other forms that have been analyzed as 'anti-utilitarian' (Romano 2015). Proscriptively, acknowledging the breadth of strategies and motivations for making a living has been central to the activist side of degrowth in its call for economic policies that make alternative lifestyle choices possible.

\section{References}

Alatas, S.H. 1977. The myth of the lazy native: a study of the image of the Malays, Filipinos and Javanese from the 16th to the 20th century and its function in the ideology of colonial capitalism. London: Frank Cass.

Anderson, D. and N. Carrier. 2011. Khat: social harms and legislation, a literature review. Home Office Occasional Paper 95. London: British Home Office.

Appadurai, A. 1988. Introduction: commodities and the politics of value. In A. Appadurai (ed.) The social life of things: commodities in cultural perspective. Cambridge: Cambridge University Press. Pp. 363. 
Blaikie, P.M. and Brookfield, H.C. (eds.) 1987. Land degradation and society. London: Methuen.

Burke, B.J., and B. Shear. 2014. Introduction: engaged scholarship for non-capitalist political ecologies. Journal of Political Ecology 21: 128-144.

Carrier, N. 2005. 'Miraa is cool': the cultural importance of miraa (khat) for Tigania and Igembe youth in Kenya. Journal of African Cultural Studies 17(2): 201-218.

Carrier, N. 2008. Is miraa a drug? Categorizing Kenyan khat. Substance Use and Misuse 43 (6): 803-818.

Carrier, N. and Gezon, L.L. 2009. Khat in the Western Indian Ocean: regional linkages and disjunctures. Etudes Océan Indien 42-43: 271-297.

Cattaneo, C., G. D'Alisa, G. Kallis and C. Zografos. 2012. Degrowth futures and democracy. Futures 44(6): 515-523.

D'Alisa, G., Demaria, F. and Kallis, G. 2015. (eds.). Degrowth: a vocabulary for a new era. London: Routledge.

Douglas, M. and Isherwood, B. 1979. The world of goods. New York: Basic Books.

Escobar, A. 2008. Territories of difference: place, movements, life, redes. Durham, USA: Duke University Press.

Escobar, A. 2015. Degrowth, postdevelopment, and transitions: a preliminary conversation. Sustainability Science 10(3): 451-462.

Ferguson, J. 2013. Declarations of dependence: labour, personhood, and welfare in southern Africa. Journal of the Royal Anthropological Institute 19(2): 223-242.

Fiske, S.J., S.A. Crate, C.L. Crumley, K. Galvin, H. Lazrus, L. Lucero, A. Oliver Smith, B. Orlove, S. Strauss and R. Wilk. 2014. Changing the atmosphere: anthropology and climate change. Final report of the AAA Global Climate Change Task Force. Arlington, USA: American Anthropological Association.

Foster, J.B. 2011. Capitalism and degrowth: an impossibility theorem. Monthly Review 62(8).

Foster, K. 2017. Work ethic and degrowth in a changing Atlantic Canada. Journal of Political Ecology 24: 633-643.

Gezon, L.L. 2006. Global visions, local landscapes: a political ecology of conservation, conflict, and control in Northern Madagascar. Lanham, MD: AltaMira Press.

Gezon, L.L. 2010a. Multi-sited ethnography: combining analysis at different scales. In I. Vaccaro, E.A. Smith and S. Aswani (eds.). Society and environment: methods and research design. Cambridge: Cambridge University Press. Pp. 238-265.

Gezon, L.L. 2010b. Leaf of paradise or aid to terrorism? cultural constructions of a drug called khat. In E.P. Durrenberger and S. Erem (eds.) Paradigms for anthropology: an ethnographic reader. Oxford: Oxford University Press. Pp. 172-188.

Gezon, L.L. 2012. Drug effects: khat in biocultural and socioeconomic perspective. Walnut Creek, CA: Left Coast Press.

Gezon, L.L. 2013. Leaf of paradise? the intricate effects of khat in Madagascar. Drugs and Alcohol Today 13 (3):194-204.

Gezon, L.L. 2016. Political ecology of a drug crop: the intricate effects of khat. In M. Singer (ed.) Companion to anthropology and environmental health. Hoboken, NY: Wiley-Blackwell. Pp. 325-347.

Gibson-Graham, J.K. 1996. The end of capitalism (as we knew it): a feminist critique of political economy. Oxford: Blackwell.

Gibson-Graham, J.K. 2014. Rethinking the economy with thick description and weak theory. Current Anthropology 55(9): 147-153. text

Gilmore, B. 2013. The world is yours: "degrowth", racial inequality and sustainability. Sustainability 5(3): 1282-1303. 
Graeber, D. 2001. Toward an anthropological theory of value: the false coin of our own dreams. New York: Palgrave Macmillan.

Gudynas, E. 2015. Buen vivir. In G. D'Alisa, F. Demaria and G. Kallis (eds.) Degrowth: a vocabulary for a new era. London: Routledge.

Harris, M. 2005. Nature makes them lazy: contested perceptions of place and knowledge in the lower Amazon floodplain of Brazil. Conservation and Society 3(2): 461.

Kallis, G., Demaria, F. and D'Alisa, G. 2015. Introduction: degrowth. In G. D'Alisa, F. Demaria and G. Kallis (eds.) Degrowth: a vocabulary for a new era. London: Routledge.

Kallis, G., Kerschner, C. and Martinez-Alier, J. 2012. The economics of Degrowth. Ecological Economics 84(1): 172-180.

Latouche, S. 2009. Farewell to growth. Malden: Polity Press.

Latouche, S. 2004. Degrowth economics. Le Monde Diplomatique. [accessed November 23, 2016].

Lesetedi, G.N. 2003. Urban-rural linkages as an urban survival strategy among urban dwellers in Botswana: the case of Broadhurst residents. Journal of Political Ecology 10(1): 37-46.

Mains, D. 2010. Chewing and dreaming: youth, imagination, and the consumption of khat in Jimma, southwestern Ethiopia. In E. Gebissa (ed.) Taking the place of food: khat in Ethiopia. Trenton, USA: Red Sea Press, Inc.

Mbima, Pierre-Ernest. 2006. Place du Français et pratiques linguistiques non conventionnelles chez les jeunes à Madagascar, Tome I. Ph.D. dissertation. Saint Denis: Université de la Réunion.

Moates, S. 2010. Clasificadores: "Living off the trash" and raising hogs at the urban margin. Culture and Agriculture 32 (2): 50-60.

Narotzky, S. 2012. Europe in crisis: grassroots economies and the anthropological turn. Etnografica 16(3): 627-638.

Narotzky, S. and N. Besnier. 2014. Crisis, value, and hope: rethinking the economy: an introduction to supplement 9. Current Anthropology 55 (Supplement 9): S4-S16.

O'Connor, J. 1988. Capitalism, nature, socialism: a theoretical introduction. Capitalism, Nature, Socialism 1: $11-38$.

Paulson, S. 2015. Political ecology. In G. D'Alisa, F. Demaria and G. Kallis (eds.) Degrowth: a vocabulary for a new era. London: Routledge.

Paulson, S. 2017. Degrowth: culture, power and change. Journal of Political Ecology 24: 425-448.

Polanyi, K. 1968 [1944]. The great transformation. Boston, MA: Beacon Press.

Polanyi, K. 1977. The economistic fallacy. Review (Fernand Braudel Center) 1(1): 9-18.

Rademacher, A. 2009. When is housing an environmental problem? Reforming informality in Kathmandu. Current Anthropology 50(4): 513-523.

Romano, O. 2015. Anti-utilitarianism. In G. D'Alisa, F. Demaria and G. Kallis (eds.) Degrowth: $a$ vocabulary for a new era. London: Routledge.

Sahlins, M. 1972. Stone age economics. New York: Aldine Publishing Company.

Sahlins, M. 1976. Culture and practical reason. Chicago: Chicago University Press.

Schmink, M. and Wood, C.H. 1987. The political ecology of Amazonia. In P.D. Little, M.M. Horowitz and E.A. Nyerges (eds.). Lands at risk in the third world: local-level perspectives. Boulder, CO: Westview Press.

Schor, J. 2010. Plenitude: the new economics of true wealth. New York: Penguin Books.

Sekulova, F. 2015. Happiness. In G. D'Alisa, F. Demaria and G. Kallis (eds.) Degrowth: a vocabulary for a new era. London: Routledge.

Sharp, L.A. 1996. The possessed and the dispossessed: spirits, identity, and power in a Madagascar migrant town. Berkeley, CA: University of California Press. 
Walsh, A. 2003. "Hot money" and daring consumption in a northern Malagasy sapphire-mining town. American Ethnologist 30(2): 290-305.

Walsh, A. 2012. After the rush: living with uncertainty in a Malagasy mining town. Africa 82(2): 235-251. Weir, S. 1985. Qat in Yemen: consumption and social change. London: Trustees of the British Museum.

Wolf, E. 1966. Peasants. Englewood Cliffs, NJ: Prentice Hall. 